\title{
PENGARUH AKUNTABILITAS DAN TRANSPARANSI TERHADAP PENGELOLAAN KEUANGAN MADRASAH DI KOTA PEKANBARU
}

\author{
Fenny Trisnawati \\ Program Studi Pendidikan Ekonomi FKIP Universitas Riau \\ E-mail: fenny.trisnawati81@gmail.com
}

\begin{abstract}
Abstrak
Penelitian ini bertujuan untuk mengetahui pengaruh akuntabilitas dan transparansi terhadap pengelolaan keuangan madrasah di kota Pekanbaru. Penelitian ini adalah penelitian deskriptif kuantitatif dengan menggunakan metode survey. Data dikumpulkan dengan menggunakan kuisioner dan observasi. Jumlah madrasah yang ada di kota Pekanbaru adalah 67, penelitian ini dilakukan terhadap tingkatan madrasah tsanawiyah dan madrasah aliyah yang berada di kota Pekanbaru baik madrasah negeri maupun madrasah swasta dengan jumlah sampel sebanyak 37 madrasah. Adapun yang menjadi sampel dalam penelitian ini adalah pimpinan madrasah, atau yang mewakili dengan teknik pengambilan sampel simple random sampling. Pengujian hipotesis secara statistik pada penelitian ini dengan menggunakan regresi berganda. Sebelum dilakukan pengujian hipotesis, terlebih dahulu dilakukan pengujian asumsi klasik. Hasil penelitian menunjukkan bahwa akuntabilitas dan transparansi mempengaruhi pengelolaan keuangan madrasah, besarnya pengaruh adalah sebesar 53,5\%.
\end{abstract}

Kata Kunci: akuntabilitas, transparansi, madrasah, pengelolaan keuangan.

\begin{abstract}
This study aims to determine the effect of accountability and transparency on the financial management of madrasah in the city of Pekanbaru. This research is descriptive quantitative research by using survey method. Data were collected using questionnaire and observation. The number of madrasah in Pekanbaru is 67, this research is conducted on two level, which is madrasah tsanawiyah and madrasah aliyah located in Pekanbaru city with 37 madrasah as a samples. As for the sample in this study is the headmaster of madrasah with simple random sampling technique. Testing hypothesis statistically with multiple regression. But, before that, we run normality test, multicolinearity test, and autocorrelation test. The results showed that accountability and transparency influenced the financial management of madrasah, the effect was $53.5 \%$.
\end{abstract}

Key Word: accountability, transparency, madrasah, financial management 


\section{PENDAHULUAN}

\section{Latar Belakang}

Reformasi yang terjadi di Indonesia berakibat pada munculnya semangat demokratis, akuntabilitas dan transparansi di sektor pemerintahan. Reformasi di berbagai bidang membawa kepada terwujudnya pelaksanan tugas dan fungsi penyelenggaraan pemerintahan negara dan pembangunan dengan berciri pada prinsip-prinsip good governance. Masyarakat memiliki harapan agar pemerintah bersungguh-sungguh dalam menanggulangi Korupsi, Kolusi dan Nepotisme (KKN), sehingga tercipta pemerintah yang bersih dan mampu menyediakan pelayanan kepada publik sebagaimana yang diharapkan oleh masyarakat.

Pelayanan kepada publik di bidang pendidikan adalah melalui sekolah, baik sekolah negeri maupun sekolah swasta. Dalam pelaksanaan penyelenggaraan pendidikan, sekolah memiliki otonomi. Model otonomi pendidikan ini adalah Manajemen Berbasis Sekolah (MBS). Sekolah mempunyai kewenangan untuk melakukan kreasi, inovasi dan improvisasi dalam mewujudkan pendidikan yang bermutu.

Konsep Manajemen Berbasis Sekolah (MBS) menjadikan pengelolaan pendidikan lebih terarah dan terkoordinasi dengan baik dari segi penyelenggaraan, pendanaan, pengembangan dan pengawasan. MBS pada intinya adalah memberikan kewenangan terhadap sekolah untuk melakukan pengelolaan dan perbaikan kualitas secara terus menerus. Dapat juga dikatakan bahwa MBS pada hakikatnya adalah penyerasian sumber daya yang dilakukan secara mandiri oleh sekolah dengan melibatkan semua kelompok kepentingan (stakeholder) yang terkait dengan sekolah secara langsung dalam pengambilan keputusan untuk memenuhi kebutuhan peningkatan mutu sekolah atau mencapai tujuan pendidikan nasional.

Tuntutan pada sektor publik adalah terciptanya akuntabilitas dan transparansi dalam pengelolaan keuangan pada lembaga publik di pusat maupun daerah, termasuk di sekolah. Masyarakat memberikan sejumlah dana kepada sekolah untuk penyelenggaraan pendidikan sebagai bentuk dukungan program sekolah, dan pihak sekolah berkewajiban untuk menyampaikan kepada masyarakat mengenai penggunaan dana tersebut. Dengan demikian, kepala sekolah perlu memiliki kemampuan untuk mengelola keuangan sekolah secara transparan, akuntabel, efektif dan efisien.

Selama ini sekolah hanya memiliki laporan-laporan dan surat-surat pertanggungjawaban sebagai bentuk transparansi pengelolaan keuangan sekolah. Sekolah diharapkan memiliki laporan pertanggungjawaban termasuk laporan keuangan sekolah yang terdiri dari neraca, laporan surplus, defisit, laporan arus kas, serta perhitungan biaya yang dihabiskan tiap siswa, sehingga pemerintah maupun stakeholders dapat mengetahui dengan lebih mudah berapa besar kebutuhan tiap murid dalam setiap bulan, semester atau tahunnya (Bastian, 2007).

Dalam perspektif akuntansi, setiap kepala sekolah wajib menyampaikan laporan di bidang keuangan, terutama mengenai penerimaan dan pengeluaran keuangan sekolah kepada Komite Sekolah dan pemerintah. Dengan demikian, standar akuntansi keuangan diberlakukan sebagai kriteria pelaporan yang disajikan bagi pihak pengelola sekolah. Hal ini akan menjamin akuntabilitas publik, khususnya bagi pengguna jasa pendidikan (Bastian, 2007). Bastian (2007) juga 
mengatakan bahwa dalam perspektif administrasi publik, tujuan manajemen keuangan pendidikan adalah membantu pengelolaan sumber keuangan organisasi pendidikan serta menciptakan mekanisme pengendalian yang tepat, bagi pengambilan keputusan keuangan dalam pencapaian tujuan organisasi pendidikan yang transparan, akuntabel dan efektif.

Kementrian agama provinsi Riau melalui bidang pendidikan madrasah menyelenggarakan pendidikan melalui madrasah-madrasah yang tersebar di ibukota dan kabupaten di provinsi Riau. Madrasah yang berada di bawah naungan Kementrian agama ini ada yang berstatus madrasah negeri dan ada yang berstatus madrasah swasta. Kepada madrasah-madrasah ini baik negeri maupun swasta diberikan dana Bantuan Operasional Sekolah (BOS). Dana BOS ini diberikan kepada madrasah berdasarkan jumlah siswa yang dimiliki oleh madrasah tersebut. Besaran dana BOS yang diberikan untuk Madrasah Ibtidaiyah adalah sebesar Rp800.000/siswa/tahun, untuk sekolah Madrasah Tsanawiyah adalah Rp1.000.000/siswa/tahun dan untuk sekolah Madrasah Aliyah adalah Rp1.400.000/siswa/tahun.

Dana BOS yang diterima oleh madrasah merupakan jumlah yang cukup besar dan seharusnya dapat digunakan untuk menunjang kegiatan operasional madrasah. Tetapi masih ditemui adanya pungutan-pungutan yang dilakukan terhadap siswa setiap bulannya. Adanya ketidak jelasan dalam hal pengelolaan keuangan sekolah menjadikan akuntabilitas dan transparansi akan sulit untuk dicapai. Belum adanya pemeriksaan dan minimnya pengawasan terhadap penggunaan dana BOS menjadikan dana BOS tersebut rentan terhadap penyelewengan.

Dari fenomena yang telah dipaparkan tersebut maka penelitian ini difokuskan pada pengelolaan keuangan sekolah yang berada di bawah naungan Direktorat Jenderal Pendidikan Islam dalam rangka meningkatkan akuntabilitas keuangan dan transparansi. Kementrian agama sebagai penyelenggara pendidikan melalui madrasah-madrasah atau sekolah yang berada di bawah naungannya, juga memberikan perhatian dan pengelolaan khusus melalui Direktorat Jenderal Pendidikan Islam. Melalui anggaran pendidikan dari pemerintah, Ditjen Pendidikan Islam berusaha meningkatkan mutu pendidikan dasar dan menengah dengan adanya wajib belajar sembilan tahun.

Untuk mewujudkan pendidikan dasar dan menengah yang bermutu maka salah satu program berskala nasional yang diterapkan adalah adanya Bantuan Operasional Sekolah (BOS). BOS diberikan kepada sekolah per tahun berdasarkan jumlah siswa yang dimiliki sekolah tersebut. Besaran dana BOS yang diterima sekolah bervariasi, tergantung kepada tingkatan sekolah, mulai dari sekolah dasar sampai dengan sekolah menengah. Makin tinggi tingkatan sekolahnya maka makin besar pula dana BOS untuk tiap anak yang akan diterima oleh sekolah. Dana BOS yang diperoleh tersebut seringkali tidak jelas penggunaannya. Padahal untuk terciptanya tata kelola yang baik harus ada kejelasan dan pertanggungjawaban dalam pengelolaan dana BOS yang sudah diterima. 


\section{Rumusan Masalah}

Secara spesifik permasalahan dalam penelitian ini adalah sebagai berikut: apakah akuntabilitas dan transparansi memiliki pengaruh terhadap pengelolaan keuangan madrasah di kota Pekanbaru? Berapa besar pengaruh akuntabilitas dan transparansi terhadap pengelolaan keuangan madrasah di kota Pekanbaru?

\section{Tujuan Penelitian}

Adapun tujuan penelitian yang ingin dicapai adalah

1. Untuk mengetahui pengaruh akuntabilitas dan transparansi terhadap pengelolaan keuangan madrasah di kota Pekanbaru.

2. Untuk mengetahui berapa besar pengaruh akuntabilitas dan transparansi terhadap pengelolaan keuangan madrasah di kota Pekanbaru.

\section{Manfaat Penelitian}

Melalui penelitian ini diharapkan dapat menambah pemahaman akan pentingnya pengelolaan keuangan madrasah melalui penerapan akuntabilitas dan transparansi.

\section{TINJAUAN TEORITIS}

\section{Teori Keagenan (Agency theory)}

Teori keagenan membahas mengenai hubungan antara principal dengan agen. Principal (pemilik) mendelegasikan wewenang kepada agen dalam hal ini manajer, untuk melaksanakan tanggungjawab dalam menjalankan organisasi atau perusahaan, termasuk dalam hal pengambilan keputusan. Hubungan keagenan yang tercipta antara pemilik dengan manajer ini adalah hubungan kerja. Hubungan kerja ini sulit untuk selaras karena adanya kepentingan yang berbeda antara keduanya. Dalam Hendriksen dan Breda (2012) dijelaskan bentuk hubungan keagenan dalam teori akuntansi positif ada 3 jenis, yaitu:

1. Antara pemilik dengan manajemen (Bonus Plan Hypothesis)

2. Antara kreditur dengan manajemen (Debt/equity Hypothesis)

3. Antara masyarakat dengan manejemen (Political Cost Hypothesis)

Hubungan antara pemilik dan manajer dapat menimbulkan ketidak seimbangan informasi yang dimiliki. Ketidak seimbangan informasi ini dikenal dengan nama informasi asimetri (asymetri information). Informasi asimetri terjadi karena salah satu pihak, yaitu manajemen perusahaan memiliki informasi lebih mengenai perusahaan yang dikelolanya dibandingkan dengan pemilik. Pengetahuan dan informasi lebih yang dimiliki oleh manajer ini mendorong manajer untuk berperilaku oportunis. Manajer cenderung untuk menyembunyikan informasi dari pemilik. Perilaku manajer ini lebih jauh akan mendorong manajer untuk mempengaruhi angka-angka yang disajikan pada laporan keuangan dengan cara melakukan manajemen laba. Guna mengatasi masalah hubungan keagenan ini maka diperlukan corporate governance. Hubungan keagenan ini menjadi dasar yang digunakan untuk memahami corporate governance.

\section{GCG dan Manfaat Penerapannya}

Suatu organisasi memerlukan suatu aturan yang memungkinkan organisasi tersebut untuk tumbuh dan berkembang menjadi lebih besar dan terus berkesinambungan dalam menjalankan usahanya. Sekolah sebagai salah satu 
bentuk organisasi yang memberikan pelayanan kepada masyarakat dalam bidang pendidikan berupa jasa pedidikan dan pengajaran yang diberikan kepada anak usia sekolah mulai dari usia 6 tahun sampai dengan 12 tahun.

Sekolah sebagai organisasi memerlulan tata kelola yang baik yang menjamin kelangsungan hidup organisasi. Karena pada dasarnya antara kepentingan pengelola dan kepentingan stakeholders berbeda akibat adanya ketidakseimbangan informasi (asymetri information). Tata kelola yang baik menjadikan suatu organisasi dapat mencapai tujuan organisasi dan mampu untuk menyelaraskan kepentingan para pemangku kepentingan (stakeholders).

Tata kelola perusahaan disebut juga dengan Good Corporate Governance (GCG). Syakhroza (2002) mendefenisikan Corporate Governance sebagai suatu sistem yang dipakai "Board" untuk mengarahkan dan mengendalikan serta mengawasi (directing, controlling and supervising) pengelolaan sumber daya organisasi secara efisien, efektif, ekonomis, dan produktif, dengan prinsip transparant, accountable, responsible, independece dan fairness dalam rangka mencapai tujuan organisasi.Monks dan Minow (2008) menjelaskan bahwa Corporate Governance adalah sistem yang mengatur dan mengendalikan perusahaan yang menciptakan nilai tambah (value added) bagi seluruh stock holders. Forum Corporate Governance for Indonesia mengartikan Corporate Governance sebagai perangkat peraturan yang mengatur hubungan antara pemegang saham, pengurus (pengelola) perusahaan, pihak kreditur, pemerintah, karyawan serta para pemegang kepentingan ekstern dan intern lainnya yang berkaitan dengan hak-hak dan kewajiban mereka atau dengan kata lain suatu sistem yang mengatur dan mengendalikan perusahaan. Dari pengeertian yang telah diuraikan sebelumnya, dapat disimpulkan bahwa Corporate Governance adalah suatu sistem yang mengatur perusahaan, agar tercipta hubungan yang harmonis antara pihak ekstern dan intern, terutama antara pemegang saham dan pengelola perusahaan, sehingga pada akhirnya dapat memberikan nilai tambah bagi seluruh pemangku kepentingan dan juga dapat mengurangi risiko yang ditanggungnya.

Di Indonesia, yang menjadi pemicu diliriknya penerapan Good Corporate Governance (GCG) adalah krisis ekonomi yang terjadi pada tahun 1998. Pada tahun 1999, berdasarkan keputusan Menko Ekuin No. KEP/31/M.EKUIN/08/1999 dibentuklah Komite Nasional Kebijakan Corporate Governance (KNKCG). Komite ini selanjutnya mengeluarkan Pedoman Good Corporate Governance yang pertama. Selanjutnya KNKCG diganti menjadi Komite Nasional Kebijakan Governance (KNKG) melalui surat keputusan Menko Bidang Perekonomian Nomor: KEP/49/M.EKON/11/2004 yang terdiri dari Sub Komite Publik dan Sub Komite Korporasi.

Tata kelola perusahaan sangat penting untuk menciptakan iklim usaha yang kondusif. Melalui diterapkannya tata kelola perusahaan yang baik, akan memberi manfaat terhadap berbagai pihak yang terkait dengan tiga pilar GCG, yaitu negara, dunia usaha dan masyarakat. Sejumlah penelitian juga menunjukkan bahwa penerapan GCG dapat menaikkan nilai perusahaan. Manfaat penerapan GCG antara lain: 
1. Dengan menerapkan GCG maka perusahaan dapat meminimalkan agency cost, yaitu biaya yang timbul sebagai akibat adanya pendelegasian kewenangan kepada manajemen.

2. Dapat meminimalkan cost of capital, yaitu biaya modal yang harus ditanggung bila perusahaan mengajukan pinjaman kepada kreditur.

3. Corporate governance menjadikan proses pengambilan keputusan lebih baik dan menghasilkan keputusan yang optimal, meningkatkan efisiensi dan tercipta budaya kerja yang lebih sehat.

4. Penerapan GCG akan meminimalkan dan menghindarkan dari tindakan penyalahgunaan wewenang oleh pihak direksi dalam pengelolaan perusahaan.

5. Dapat meningkatkan nilai perusahaan di mata investor sebagai akibat dari meningkatnya kepercayaan mereka kepada perusahaan tempat mereka berinvestasi.

6. Dengan adanya peningkatan kinerja, maka bagi pemegang saham akan menaikkan nilai saham mereka dan nilai dividen yang akan diterima.

7. Dalam praktik GCG, karyawan ditempatkan posisinya sebagai stakeholders, maka motivasi dan kepuasan kerja karyawan diperkirakan akan meningkat.

8. Pelaksanaan GCG yang baik akan meningkatkan tingkat kepercayaan stakeholders dan pada akhirnya akan tercipta citra positif perusahaan.

9. Penerapan GCG yang konsisten akan meningkatkan kualitas laporan keuangan.

Dengan dipaparkannya sejumlah manfaat dari penerapan GCG, maka sudah sewajarnya bila GCG dikatakan sebagai solusi untuk menjawab permasalahan pengelolaan di perusahaan yang semakin kompleks. Namun sayangnya, dalam kurun waktu lebih dari 1 dekade sejak mulai diperkenalkannya GCG di Indonesia, GCG dipandang tidak lebih dari sebagai wujud kepatuhan terhadap peraturan yang ada. Padahal esensi dari GCG sendiri lebih dari itu, karena salah satu upaya untuk meningkatkan pertumbuhan perusahaan adalah penerapan GCG yang berkesinambungan.

Pada hakekatnya, GCG dalam penerapannya memiliki beberapa prinsip, yaitu:

1. Transparansi (Transparency), diartikan sebagai keterbukaan dalam proses pengambilan keputusan dan keterbukaan dalam mengemukakan informasi materiil dan relevan mengenai perusahaan.

2. Akuntabilitas (Accountability), diartikan sebagai kejelasan fungsi, sturktur, sistem, dan pertanggungjawaban organ perusahaan sehingga pengelolaan perusahaan terlaksana secara efektif.

3. Pertanggungjawaban (Responsibility), yaitu kesesuaian (kepatuhan) didalam pengelolaan perusahaan terhadap prinsip korporasi yang sehat serta peraturann perundangan yang berlaku.

4. Kemandirian (Independency), yaitu suatu keadaan dimana perusahaan dikelola secara profesional tanpa benturan kepentingan dan pengaruh/tekanan dari pihak manajemen yang tidak sesuai dengan peraturan dan perundangan yan berlaku dan prinsip korporasi yang sehat.

5. Kesetaraan dan kewajaran (Fairness), yaitu perlakuan yang adil dan setara didalam memenuhi hak-hak stakeholders yang timbul berdasarkan perjanjian serta peraturan perundangan yang berlaku. 


\section{Manajemen Keuangan Sekolah}

Perencanaan dan pengendalian manajerial merupakan suatu proses siklus yang berlanjut dan saling berkesinambungan, sehingga salah satu tahap akan terkait dengan tahap yang lain dan terintegrasi dalam satu organisasi. Jones dan Pendlebury dalam Mardiasmo (2002) membagi proses perencanaan dan pengendalian manajerial pada organisasi sektor publik menjadi lima tahap, yaitu:

1. Perencanaan tujuan dan sasaran dasar. Tahap ini merupakan proses perumusan tujuan dasar dari organisasi yang tergambarkan dengan visi dan misi organisasi. Perencanaan ini dirumuskan dan disusun oleh manajemen tingkat atas dan merupakan proses perencanaan yang rumit dan pelik karena menyangkut keberlangsungan organisasi dan terkait dengan harapan dan tujuan dasar organisasi.

2. Perencanaan operasional. Tahap ini merupakan perencanaan yang dirumuskan dan disusun untuk tercapainya tujuan dan sasaran dasar organisasi

3. Penganggaran. Tahap ini adalah tahap proses penyusunan anggaran untuk mendukung perencanaan operasional yang telah disusun serta untuk melaksanakan tujuan-tujuan dan target-target organisasi dalam jangka pendek (kegiatan operasional).

4. Pengendalian dan pengkuran. Tahap ini merupakan proses pengendalian, pengawasan dan pengukuran atas anggaran yang telah disepakati untuk dilaksanakan. Tahap ini juga merupakan proses pelaksanaan tujuan-tujuan dan target-target jangka pendek organisasi (kegiatan operasional)

5. Pelaporan, analisis dan umpan balik. Tahap ini merupakan proses akhir dari siklus perencanaan dan pengendalian manajerial. Tahap ini terdiri atas proses pelaporan hasil kegiatan operasional yang telah dicapai selama periode berlangsung, analisa atas seluruh kegiatan yang telah dilaksanakan maupun kegiatan yang gagal dilaksanakan, serta umpan balik untuk pelaksanaan kegiatan periode berlangsung ataupun periode berikutnya.

Manajemen keuangan merupakan manajemen terhadap fungsi-fungsi keuangan, sedangkan fungsi keuangan merupakan kegiatan utama yang harus dilakukan oleh mereka yang bertanggungjawab di dalam bidang tertentu. Fungsi manajemen keuangan adalah menggunakan dana serta mendapatkan dana (Suad Husnan, 1992).

Manajemen keuangan sekolah merupakan rangkaian aktivitas mengatur keuangan sekolah yang dimulai dari perencanaan, pembukuan, pembelanjaan, pengawasan dan pertanggungjawaban keuangan sekolah. Menurut Bafadal (2004), manajemen keuangan sekolah dapat diartikan sebagai keseluruhan proses pemerolehan dan pendayagunaan uang secara tertib, efisien dan dapat dipertanggungjawabkan dalam rangka memperlancar pencapaian tujuan pendidikan. Berdasarkan defenisi tersebut, ada empat hal yang perlu digarisbawahi terkait dengan manajemen keuangan sekolah, antara lain sebagai berikut:

1. Manajemen keuangan merupakan keseluruhan proses upaya memperoleh serta mendayagunakan seluruh dana. 
2. Mencari sebanyak mungkin sumber-sumber keuangan serta berusaha semaksimal mungkin untuk mendapatkan dana dari sumber-sumber keuangan tersebut.

Menurut Depdiknas (2007), sumber-sumber pendapatan sekolah dapat berasal dari:

1. Pemerintah, yang meliputi pemerintah pusat, yang dialokasikan melalui APBN serta pemerintah kabupaten/kota yang dialokasikan melalui APBD.

2. Usaha mandiri sekolah, yang berupa kegiatan pengelolaan kantin sekolah, koperasi sekolah, jasa antara jemput siswa, panen kebun sekolah, kegiatan sekolah yang menarik sehingga ada sponsor yang memberi dana, kegiatan pelatihan/seminar/lokakarya dengan dana dari peserta yang dapat disisihkan sisa anggarannya untuk sekolah, serta penyelenggaraan lomba kesenian dengan biaya dari peserta atau perusahaan yang dapat disisihkan sebagian dananya untuk sekolah.

3. Orang tua siswa, yang berupa sumbangan fasilitas belajar siswa, sumbangan pembangunan gedung, iuran BP3 dan SPP

4. Dunia usaha dan industri, yang dilakukan melalui kerjasama dalam berbagai kegiatan, baik berupa bantuan uang maupun fasilitas sekolah

5. Hibah yang tidak bertentangan dengan peraturan perundangan yang berlaku, dimana kepala sekolah perlu menyusun proposal yang menguraikan kebutuhan pengembangan program sekolah

6. Yayasan penyelenggara pendidikan bagi lembaga pendidikan swasta.

7. Masyarakat luas

Menurut Bastian (2007) ada tiga anggaran publik dalam anggaran pendidikan yang harus kita perhatikan, yaitu:

1. Anggaran Pendapatan dan Belanja Negara (APBN) yang dikelola oleh pemerintah pusat.

2. Anggaran Pendapatan dan Belanja Daerah (APBD) yang dikelola oleh pemerintah daerah.

3. Anggaran Pendapatan dan Belanja Sekolah (APBS) yang dikelola oleh satuan pendidikan (sekolah).

Pengelolaan dana pendidikan menjadi tanggungjawab bersama antara pemerintah pusat maupun pemerintah daerah dan masyarakat. Dalam pengelolaan dana pendidikan haruslah mengacu kepada prinsip:

a. Prinsip keadilan

b. Prinsip efisiensi

c. Prinsip transparansi

d. Prinsip akuntabilitas publik

Prinsip akuntabilitas publik dan prinsip transparansi menjadi indikator utama dalam penilaian pengelolaan keuangan madrasah. Pengelolaan keuangan madrasah adalah seluruh upaya yang dilakukan pengelola madrasah agar komponen keuangan dan pembiayaan dikelola sebaik-baiknya, agar tujuan madrasah dapat tercapai. Indikator pengelolaan keuangan madrasah dalam penelitian ini adalah:

1. Adanya proses merencanakan kegiatan yang akan dilaksanakan madrasah yang kemudian dibuat anggaran penerimaan dan belanja madrasah 
2. Adanya proses mengorganisasikan, mengarahkan dan mengkoordinasikan yang dilakukan oleh kepala madrasah.

3. Adanya proses melaksanakan kemudian melaporkan, supaya setiap kegiatan madrasah tercatat dengan rinci penerimaan dan pengeluarannya.

4. Adanya pengawasan baik pihak internal madrasah (kepala sekolah) maupun pihak eksternal madrasah (misalnya oleh BPK).

\section{Akuntabilitas}

Isu akuntabilitas akhir-akhir ini semakin gencar dibicarakan seiring dengan adanya tuntutan masyarakat akan pendidikan yang bermutu. Bahkan resonansinya semakin keras, sekeras tuntutan akan reformasi dalam segala bidang. Ini membuktikan bahwa kecenderungan masyarakat pada masa kini berbeda dengan masa lalu. Fasli Jalal dan Dedi Supriadi (2001) menyatakan: Bila di masa lalu masyarakat cenderung menerima apa pun yang diberikan oleh pendidikan, maka sekarang mereka tidak dengan mudah menerima apa yang diberikan oleh pendidikan. Masyarakat yang notabene membayar pendidikan merasa berhak untuk memperoleh pendidikan yang lebih baik bagi dirinya dan anak-anaknya.

Bagi lembaga-lembaga pendidikan hal ini mulai disadari dan disikapi dengan melakukan redesain sistem yang mampu menjawab tuntutan masyarakat. Caranya adalah mengembangkan model manajemen pendidikan yang akuntabel.

Akuntabilitas adalah kewajiban untuk memberikan pertanggungjawaban atau untuk menjawab dan menerangkan kinerja dan tindakan penyelenggara organisasi kepada pihak yang memiliki hak atau kewajiban untuk meminta keterangan atau pertanggungjawaban. Zamroni (2008) mendefinisikan akuntabilitas is the degree to which local governments have to explain or justify what they have done or failed to do. Lebih lanjut dikemukakan bahwa Accountability can be seen as validation of participation, in that the test of whether attempts to increase participation prove successful is the extent to which people can use participation to hold a local government responsible for its action. Pendapat Zamroni mengenai akuntabilitas dikaitkan dengan partisipasi. Ini berarti akuntabilitas hanya dapat terjadi jika ada partisipasi dari stakeholders sekolah. Semakin kecil partisipasi stakeholders dalam penyelenggaraan manajemen sekolah, maka akan semakin rendah pula akuntabilitas sekolah.

Asian Development Bank menegaskan adanya konsensus umum bahwa good governance dilandasi oleh 4 pilar yaitu (1) akuntabilitas, (2) transparansi, (3) dapat di prediksi, dan (4) partisipasi (ADB, 2008). Jelas bahwa jumlah komponen atau pun prinsip yang melandasi tata pemerintahan yang baik sangat bervariasi dari satu institusi ke institusi lain, dari satu pakar ke pakar lainnya. Namun paling tidak ada sejumlah prinsip yang dianggap sebagai prinsip-prinsip utama yang melandasi good governance, yaitu (1) Akuntabilitas, (2) Transparansi, dan (3) Partisipasi Masyarakat.

Ketiga prinsip tersebut di atas tidaklah dapat berjalan sendiri-sendiri, ada hubungan yang sangat erat dan saling mempengaruhi, masing-masing adalah instrumen yang diperlukan untuk mencapai prinsip yang lainnya, dan ketiganya adalah instrumen yang diperlukan untuk mencapai manajemen publik yang baik. Walaupun begitu, akuntabilitas menjadi kunci dari semua prinsip ini. Prinsip ini 
menuntut dua hal yaitu (1) kemampuan menjawab (answerability), dan (2) konsekuensi (consequences). Komponen pertama (istilah yang bermula dari responsibilitas) adalah berhubungan dengan tuntutan bagi para aparat untuk menjawab secara periodik setiap pertanyaan-pertanyaan yang berhubungan dengan bagaimana mereka menggunakan wewenang mereka, kemana sumber daya telah dipergunakan, dan apa yang telah dicapai dengan menggunakan sumber daya tersebut.

Guy Peter (2000) menyebutkan adanya 3 tipe akuntabilitas yaitu : (1) akuntabilitas keuangan, (2) akuntabilitas administratif, dan (3) akuntabilitas kebijakan publik. Akuntabilitas publik adalah prinsip yang menjamin bahwa setiap kegiatan penyelenggaraan pemerintahan dapat dipertanggungjawabkan secara terbuka oleh pelaku kepada pihak-pihak yang terkena dampak penerapan kebijakan.

Pengambilan keputusan didalam organisasi-organisasi publik melibatkan banyak pihak. Oleh karena itu, wajar apabila rumusan kebijakan merupakan hasil kesepakatan antara warga pemilih (constituency) para pimpinan politik, teknokrat, birokrat atau administrator, serta para pelaksana dilapangan. Sedangkan dalam bidang politik, yang juga berhubungan dengan masyarakat secara umum, akuntabilitas didefinisikan sebagai mekanisme penggantian pejabat atau penguasa, tidak ada usaha untuk membangun monoloyalitas secara sistematis, serta ada definisi dan penanganan yang jelas terhadap pelanggaran kekuasaan dibawah rule of law.

Akuntabilitas yang tinggi hanya dapat dicapai dengan pengelolaan sumber daya sekolah secara efektif dan efisien. Akuntabilitas tidak datang dengan sendiri setelah lembaga-lembaga pendidikan melaksanakan usaha-usahanya. Tiga hal yang berkaitan dalam lembaga pendidikan adalah kompetensi, akreditasi dan akuntabilitas. Seorang lulusan yang memenuhi syarat dan sudah memiliki kompetensi sesuai dengan yang disyaratkan oleh lembaga pendidikan akan berhak memperoleh sertifikat. Lembaga pendidikan yang dapat menjamin mutu lulusan yang dihasilkan disebut sebagai lembaga pendidikan yang sudah terakreditasi. Lembaga pendidikan dikatakan akuntabel jika dapat menjaga mutunya dan dapat menghasilkan lulusan yang bermutu.

Institusi pendidikan yang akuntabel adalah institusi pendidikan yang mampu menjaga mutu keluarannya sehingga dapat diterima oleh masyarakat. Jadi, dalam hal ini akuntabel tidaknya suatu lembaga pendidikan bergantung kepada mutu outputnya, ini disebut sebagai akuntabilitas kinerja. Di samping itu, akuntabilitas suatu lembaga juga bergantung kepada kemampuan suatu lembaga pendidikan mempertanggungjawabkan pengelolaan keuangan kepada publik atau disebut juga akuntabilitas keuangan.

Tujuan akuntabilitas adalah agar terciptanya kepercayaan publik terhadap sekolah. Kepercayaan publik yang tinggi akan sekolah dapat mendorong partisipasi yang lebih tinggi pula terdapat pengelolaan manajemen sekolah. Sekolah akan dianggap sebagai agen bahkan sumber perubahan masyarakat. Akuntabilitas bertujuan untuk mendorong terciptanya akuntabilitas kinerja sekolah sebagai salah satu syarat untuk terciptanya sekolah yang baik dan terpercaya. Penyelenggara sekolah harus memahami bahwa mereka harus mempertanggungjawabkan hasil kerja kepada publik. Selain itu, tujuan akuntabilitas adalah menilai kinerja sekolah 
dan kepuasaan publik terhadap pelayanan pendidikan yang diselenggarakan oleh sekolah, untuk mengikutsertakan publik dalam pengawasan pelayanan pendidikan dan untuk mempertanggungjawabkan komitmen pelayanan pendidikan kepada publik.

Sekolah sebagai tempat penyelenggaran manajemen yang akuntabel merupakan suatu pranata sosial. Dikatakan sebagai pranata sosial karena di tempat tersebut terdapat orang-orang dari berbagai latar belakang sosial yang membentuk suatu kesatuan dengan nilai-nilai dan budaya tertentu. Nilai-nilai dan budaya tersebut potensial untuk mendukung penyelenggaraan manajemen sekolah yang akuntabel, tetapi juga sebaliknya bisa menjadi penghambat. Para manejer harus mengubah filosofi mereka dari memperlakukan setiap orang dengan cara yang sama menjadi mengenali perbedaan dan menyikapi mereka yang berbeda dengan caracara yang menjamin kesetiaan karyawan dan peningkatan produktifitas sementara, pada saat yang sama, tidak melakukan diskriminasi.

Jadi, faktor yang mempengaruhi akuntabilitas terletak pada dua hal, yakni faktor sistem dan faktor orang. Sistem menyangkut aturan-aturan, tradisi organisasi. Sedangkan faktor orang menyangkut motivasi, persepsi dan nilai-nilai yang dianutnya mempengaruhi kemampuan akuntabilitas. Kalau ditelusuri lebih jauh faktor orang sendiri sebenarnya tidak berdiri sendiri, melainkan merupakan produk dari masyarakat dengan budaya tertentu.

Rumusan tujuan akuntabilitas di atas hendak menegaskan bahwa, akuntabilitas bukanlah akhir dari sistem penyelenggaran manajemen sekolah, tetapi merupakan faktor pendorong munculnya kepercayaan dan partisipasi yang lebih tinggi lagi. Bahkan, boleh dikatakan bahwa akuntabilitas baru sebagai titik awal menuju keberlangsungan manajemen sekolah yang berkinerja tinggi.

Ada delapan hal yang harus dikerjakan oleh sekolah untuk peningkatan akuntabilitas: Pertama, sekolah harus menyusun aturan main tentang sistem akuntabilitas termasuk mekanisme pertanggungjawaban. Kedua, sekolah perlu menyusun pedoman tingkah laku dan sistem pemantauan kinerja penyelenggara sekolah dan sistem pengawasan dengan sanksi yang jelas dan tegas. Ketiga, sekolah menyusun rencana pengembangan sekolah dan menyampaikan kepada publik/stakeholders di awal setiap tahun anggaran. Keempat, menyusun indikator yang jelas tentang pengukuran kinerja sekolah dan disampaikan kepada stakeholders. Kelima, melakukan pengukuran pencapaian kinerja pelayanan pendidikan dan menyampaikan hasilnya kepada publik/stakeholders diakhir tahun. Keenam, memberikan tanggapan terhadap pertanyaan dan pengaduan publik. Ketujuh, menyediakan informasi kegiatan sekolah kepada publik yang akan memperoleh pelayanan pendidikan. Kedelapan, memperbaharui rencana kinerja yang baru sebagai kesepakatan komitmen baru.

Kedelapan upaya di atas, semuanya bertumpu pada kemampuan dan kemauan sekolah untuk mewujudkannya. Alih-alih sekolah mengetahui sumber dayanya, sehingga dapat digerakan untuk mewujudkan dan meningkatkan akuntabilitas. Sekolah dapat melibatkan stakeholders untuk menyusun dan memperbaharui sistem yang dianggap tidak dapat menjamin terwujudnya akuntabilitas di sekolah. Komite sekolah, orang tua siswa, kelompok profesi, dan 
pemerintah dapat dilibatkan untuk melaksanakannya. Dengan begitu stakeholders sejak awal tahu dan merasa memiliki akan sistem yang ada.

Secara garis besar dapat disimpulkan bahwa akuntabilitas berhubungan dengan kewajiban dari institusi pemerintahan maupun para aparat yang bekerja di dalamnya untuk membuat kebijakan maupun melakukan aksi yang sesuai dengan nilai yang berlaku maupun kebutuhan masyarakat. Akuntabilitas publik menuntut adanya pembatasan tugas yang jelas dan efisien dari para aparat birokrasi. Karena pemerintah bertanggungjawab baik dari segi penggunaan keuangan maupun sumber daya publik dan juga akan hasil, akuntabilitas internal harus dilengkapi dengan akuntabilitas eksternal, melalui umpan balik dari para pemakai jasa pelayanan maupun dari masyarakat.

Definisi konseptual akuntabilitas dalam penelitian ini adalah suatu ukuran yang menunjukkan seberapa besar tingkat kesesuaian penyelenggaraan pelayanan dengan ukuran nilai-nilai atau norma-norma eksternal yang dimiliki oleh para pemangku kepentingan yang berkepentingan dengan pelayanan tersebut. Indikator pada penelitian ini adalah:

1. Kualitas penyusunan APBM (Anggaran Pendapatan dan Belanja Madrasah). Yang menjadi perhatian adalah dalam ketepatan waktu penyusunan APBM dan kemampuan APBM untuk mengakomodir kepentingan seluruh warga madrasah.

2. Laporan keuangan periodik dan pertanggungjawaban tahunan

3. Partisipasi stakeholders dalam mencipatakan akuntabilitas.

4. Akuntabilitas secara keseluruhan

\section{Transparansi}

Transparansi adalah prinsip yang menjamin akses atau kebebasan bagi setiap orang untuk memperoleh informasi tentang penyelenggaraan pemerintahan, yakni informasi tentang kebijakan, proses pembuatan dan pelaksanaannya, serta hasil-hasil yang dicapai. Transparansi yakni adanya kebijakan terbuka bagi pengawasan. Sedangkan yang dimaksud dengan informasi adalah informasi mengenai setiap aspek kebijakan pemerintah yang dapat dijangkau oleh publik.

Komunikasi publik menuntut usaha positif dari pemerintah untuk membuka dan menyebarkan informasi maupun aktivitasnya yang relevan. Transparansi harus seimbang dengan kebutuhan akan kerahasiaan lembaga maupun informasiinformasi yang mempengaruhi hak privasi individu. Karena pemerintahan menghasilkan data dalam jumlah besar, maka dibutuhkan petugas informasi professional, bukan untuk membuat dalih atas keputusan pemerintah, tetapi untuk menyebarluaskan keputusan-keputusan yang penting kepada masyarakat serta menjelaskan alasan dari setiap kebijakan tersebut.

Peran media juga sangat penting bagi transparansi pemerintah, baik sebagai sebuah kesempatan untuk berkomunikasi pada publik maupun menjelaskan berbagai informasi yang relevan, juga sebagai "watchdog" atas berbagai aksi pemerintah dan perilaku menyimpang dari para aparat birokrasi. Jelas, media tidak akan dapat melakukan tugas ini tanpa adanya kebebasan pers, bebas dari intervensi pemerintah maupun pengaruh kepentingan bisnis. 
Keterbukaan membawa konsekuensi adanya kontrol yang berlebihan dari masyarakat dan bahkan oleh media massa. Karena itu, kewajiban akan keterbukaan harus diimbangi dengan nilai pembatasan, yang mencakup kriteria yang jelas dari para aparat publik tentang jenis informasi apa saja yang mereka berikan dan pada siapa informasi tersebut diberikan.

Sebelum era desentralisasi dan reformasi, pengelolaan pendidikan dibanyak sekolah sangat tertutup bagi pihak luar. Masyarakat, orang tua murid dan sebagian besar guru tidak banyak mengetahui seluk beluk pengelolaan pendidikan di sekolah, tidak mengetahui pendapatan dan belanja sekolah, tidak dilibatkan di dalam mengevaluasi kekuatan dan kelemahan kinerja sekolah dsb.

Pengelolaan yang tidak transparan berdampak negatif bagi pengembangan sekolah karena masyarakat dan orang tua murid akan meragukan apakah kalau mereka diminta untuk ikut memikirkan kekurangan pendanaan pendidikan, sumbangan yang mereka berikan akan benar-benar dimanfaatkan bagi kepentingan pendidikan atau akan terjadi penyimpangan yang tidak diharapkan. Dilain pihak, pimpinan sekolah yang menerapkan pengelolaan tertutup merasa bahwa pihak lain tidak perlu ikut campur dengan masalah pengelolaan sekolah karena sudah cukup ditangani oleh kepala sekolah dan satu dua orang staf kepercayaan kepala sekolah. Mereka khawatir keterbukaan akan sangat merepotkan dan tidak dapat memecahkan masalah yang dihadapi sekolah.

Sebenarnya kekhawatiran seperti itu tidak perlu, karena pengalaman lapangan menunjukkan bahwa semakin tinggi transparansi pengelolaan suatu sekolah, semakin tinggi pula kepercayaan masyarakat dan rasa ikut memiliki sekolah, dan semakin banyak sumbangan pemikiran, dana dan fasilitas lain yang diperoleh sekolah dari masyarakat dan pihak terkait lainnya. Transparansi menciptakan kepercayaan timbal balik antara pemerintah/sekolah dan masyarakat, melalui penyediaan informasi dan menjamin kemudahan dalam memperoleh informasi yang memadai.

Transparansi pengelolaan antara lain mencakup: 1) Pengelolaan keuangan, keterbukaan dalam pendapatan dan belanja sekolah baik dari pemerintah, donor maupun sumber-sumber lain, 2) Pengelolaan staf /personalia : kebutuhan ketenagaan, kualifikasi, kemampuan dan kelemahan, kebutuhan pengembangan professional, dsb. 3) Pengelolaan kurikulum, termasuk keterbukaan dalam hal prestasi dan kinerja siswa, ketersediaan sarana dan prasarana penunjang pelaksanaan kurikulum, visi, misi, dan program peningkatan mutu pendidikan.

Definisi konseptual transparansi dalam penelitian ini adalah prinsip yang menjamin akses atau kebebasan bagi setiap pemangku kepentingan madrasah untuk memperoleh informasi tentang pengelolaan keuangan madrasah, yakni informasi tentang kebijakan, proses pembuatan dan pelaksanaannya, serta hasil-hasil yang dicapai madrasah. Berdasarkan penjelasan sebelumnya, maka indikator transparansi adalah:

1. Kejelasan peran dan tanggung jawab pengelola keuangan sekolah.

2. Ketersediaan informasi bagi publik

3. Penyusunan, pelaporan dan pelaksanaan anggaran sekolah secara terbuka

4. Jaminan integritas, adanya kemudahan bagi warga madrasah dan komite madrasah untuk meminta laporan keuangan madrasah. 


\section{METODE PENELITIAN}

Penelitian ini seluruhnya dilakukan pada madrasah yang ada di kota Pekanbaru. Jenis penelitian ini adalah deskriptif menggunakan metode survey. Objek penelitian ini adalah madrasah-madrasah di kota Pekanbaru yang berada di bawah naungan Kementrian Agama Provinsi Riau. Meliputi Madrasah Ibtidaiyah (MI), Madrasah Tsanawiyah (MTs) dan Madrasah Aliyah (MA).

Populasi dalam penelitian ini adalah seluruh madrasah pada berbagai tingkatan di kota Pekanbaru baik negeri maupun swasta yang berjumlah 67 madrasah. Sampel dalam penelitian ini adalah simple random sampling dan diambil dari pimpinan pada masing-masing madrasah. Pimpinan yang dimaksud dalam penelitian ini adalah kepala madrasah dan wakil kepala madrasah. Probabilitas keyakinan penelitian ini adalah $95 \%$.

Rumus untuk menentukan ukuran sampel adalah :

Keterangan :

$$
\mathrm{n}=\frac{\mathrm{N}}{\mathrm{N}(\mathrm{d})^{2}+1}
$$

$\mathrm{n} \quad$ = jumlah sampel

$\mathrm{N}=$ jumlah populasi yang diketahui

$\mathrm{d}=$ presisi yang ditetapkan

$1=$ konstanta

Dengan menggunakan rumus tersebut, maka dapat diketahui besarnya sampel yang diperoleh adalah sebagai berikut:

$$
\begin{aligned}
& n=\frac{67}{67(0,05)^{2}+1} \\
& n=\frac{67}{1.1675}=57,38 \\
& n=57
\end{aligned}
$$

Maka jumlah sampel yang diteliti adalah 57 madrasah. Kemudian ditentukan jumlah masing-masing sampel penelitian pada masing-masing tingkatan madrasah seperti terlihat pada tabel 1. Madrasah Ibtidaiyah (MI) tidak dimasukkan menjadi sampel karena MI bukan lagi sebagai satuan kerja pada Kementrian Agama. Sehingga dengan adanya pengurangan sampel, maka sampel pada penelitian ini berjumlah 37 madrasah, yang terdiri dari Madrasah Tsanawiyah dan Madrasah Aliyah.

\section{Tabel 1. Jumlah Sampel Madrasah di Kota Pekanbaru}

\begin{tabular}{|c|l|c|c|}
\hline No. & \multicolumn{1}{|c|}{ Tingkatan Madrasah } & Populasi & Jumlah Sampel \\
\hline 1 & Madrasah Ibtidaiyah & 23 & 20 \\
\hline 2 & Madrasah Tsanawiyah & 30 & 25 \\
\hline 3 & Madrasah Aliyah & 14 & 12 \\
\hline
\end{tabular}




\begin{tabular}{|c|c|c|}
\hline Jumlah & $\mathbf{6 7}$ & $\mathbf{5 7}$ \\
\hline
\end{tabular}

Jenis data yang digunakan pada penelitian ini adalah data primer dan data sekunder, dengan teknik pengumpulan data yang digunakan adalah sebagai berikut: a. Wawancara dengan menggunakan kuesioner. Untuk itu disiapkan kuesioner yang ditujukan untuk pimpinan madrasah yang terdiri dari kepala madrasah dan wakil kepala madrasah.

b. Wawancara lansung tanpa kuesioner terhadap pimpinan madrasah.

c. Observasi terhadap semua objek penelitian yang ditujukan untuk melengkapi dan mencek data yang diperlukan.

Data yang telah terkumpul selanjutnya akan dianalisis dengan analisis regresi berganda. Namun sebelum itu dilakukan pengujian normalitas data, pengujian multikolinearitas dan pengujian autokorelasi.

\section{HASIL PENELITIAN DAN PEMBAHASAN}

\section{Hasil Penelitian}

\subsection{Uji Normalitas Data}

Pengujian normalitas data dilakukan dengan statistik uji KolmogrovSmirnov. Pada tabel 2 terlihat nilai signifikansi sebesar 0,833. Nilai ini lebih besar dari 0,05 . Hal ini memiliki arti bahwa distribusi data pada penelitian ini adalah normal. Distribusi data normal adalah salah satu asumsi yang harus dipenuhi untuk melakukan analisis regresi berganda.

\section{Tabel 2 Pengujian Normalitas Data}

\subsection{Uji Multikolinearitas}

One-Sample Kolmogorov-Smirnov Test

\begin{tabular}{|ll|r|}
\hline & & Unstandardized Residual \\
\hline Normal Parameters ${ }^{\mathrm{a}, \mathrm{b}}$ & Mean & 37 \\
& Std. Deviation & .0000000 \\
& & 7.19884602 \\
Most Extreme Differences & Absolute & .102 \\
& Positive & .077 \\
& Negative & -.102 \\
Kolmogorov-Smirnov Z & & .623 \\
Asymp. Sig. (2-tailed) & & .833 \\
\hline a. Test distribution is Normal. & & \\
b. Calculated from data. & & \\
Asumsi kedua yang &
\end{tabular}

Asumsi kedua yang harus dipenuhi dalam melakukan analisis regresi berganda adalah tidak adanya multikolinearitas antara variabel independen. Pengujian ini dilakukan dengan melihat nilai VIF. Bila nilai VIF lebih besar dari 10, artinya terdapat gejala multikolinearitas. Pada tabel 3 nilai VIF pada masingmasing variabel independen adalah sebesar 1,594. Nilai ini lebih kecil dari 10, 
artinya tidak terdapat gejala multikolinearitas, atau disebut juga tidak terdapat hubungan linear yang sangat tinggi antara variabel independen.

\section{Tabel 3 Pengujian Multikolinearitas}

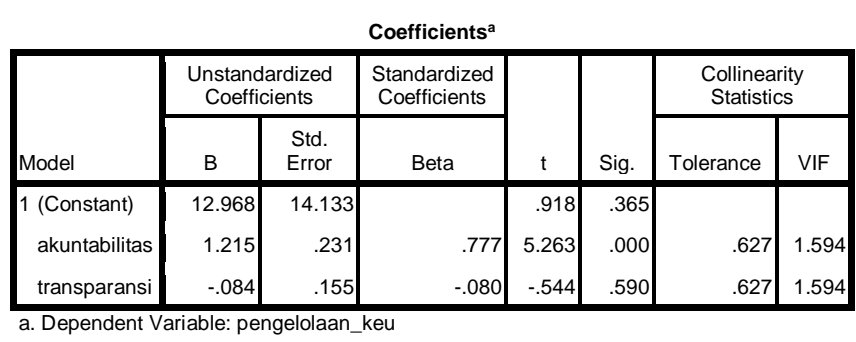

\subsection{Uji Autokorelasi}

Asumsi yang juga harus dipenuhi dalam melakukan analisis regresi berganda adalah tidak adanya autokorelasi yang ditunjukkan oleh nilai DurbinWatson. Berdasarkan tabel Durbin-Watson dengan sampel sebanyak 37 dan banyaknya variabel adalah 3, diperoleh nilai batas atas (dU) adalah 1,59044 dan nilai batas bawah (dL) sebesar 1,36354. Pada tabel 4, nilai Durbin-Watson adalah 1,746. Dinyatakan tidak terdapat gejala autokorelasi jika $\mathrm{dU}<\mathrm{d}<4$-dU. Dari uraian sebelumnya dapat dikatakan tidak terdapat gejala autokorelasi pada data penelitian ini, sehingga dapat dilakukan analisis regresi linear berganda.

\section{Tabel 4 Model Summary}

\begin{tabular}{|c|c|c|c|c|c|}
\hline \multicolumn{6}{|c|}{ Model Summaryb } \\
\hline Model & $\mathrm{R}$ & $\begin{array}{c}\mathrm{R} \\
\text { Square }\end{array}$ & \begin{tabular}{|c|} 
Adjust \\
ed $R$ \\
Squar \\
e
\end{tabular} & $\begin{array}{c}\text { Std. Error } \\
\text { of the } \\
\text { Estimate }\end{array}$ & $\begin{array}{l}\text { Durbin- } \\
\text { Watson }\end{array}$ \\
\hline 1 & $.731^{\mathrm{a}}$ & .535 & .507 & 7.407551 & 1.746 \\
\hline
\end{tabular}

\subsection{Pengujian Hipotesis}

Setelah asumsi untuk melakukan analisis regresi terpenuhi, maka selanjutnya dilakukan uji hipotesis. Pada tabel 3 diperoleh nilai t hitung sebesar 5,263 pada variabel akuntabilitas. Nilai ini lebih besar dari t tabel 2,032 dengan nilai signifikansi $(0,000)$ lebih kecil dari 0,05 . Hal ini berarti bahwa terdapat pengaruh yang signifikan antara akuntabilitas terhadap pengelolaan keuangan. Pada variabel transparansi, nilai t hitungnya sebesar $-0,544$. Nilai ini lebih kecil dari t tabel dan nilai signifikansi $(0,590)$ lebih besar dari 0,05 . Hal ini berarti bahwa tidak terdapat pengaruh yang signifikan antara transparansi terhadap pengelolaan keuangan. 
Untuk mengetahui pengaruh variabel independen terhadap variabel dependen secara simultan (bersama-sama) dapat digunakan nilai F. Pada tabel 5, terlihat nilai $F$ hitung sebesar 19, 535. Nilai ini lebih besar daripada nilai $F$ tabel yaitu 3,267. Hal ini berarti variabel akuntabilitas dan variabel transparansi secara simultan berpengaruh terhadap variabel pengelolaan keuangan.

\section{Tabel 5 Output Anova dalam Regresi}

\begin{tabular}{l|r|r|r|r|r|}
\hline Model & $\begin{array}{c}\text { Sum of } \\
\text { Squares }\end{array}$ & df & \multicolumn{1}{|c|}{$\begin{array}{c}\text { Mean } \\
\text { Square }\end{array}$} & F & Sig. \\
\hline 1 Regression & 2143.873 & 2 & 1071.936 & 19.535 & $.000^{\mathrm{a}}$ \\
Residual & 1865.642 & 34 & 54.872 & & \\
Total & 4009.515 & 36 & & & \\
\hline
\end{tabular}
a. Predictors: (Constant), transparansi, akuntabilitas
b. Dependent Variable: pengelolaan_keu

Untuk melihat besarnya pengaruh variabel akuntabilitas dan transparansi terhadap pengelolaan keuangan dapat dilihat pada tabel 4. Pada tabel tersebut nilai R square sebesar 0,535 atau 53,5\%.

\section{Pembahasan}

Pada hasil penelitian secara parsial menunjukkan bahwa variabel akuntabilitas memiliki pengaruh signifikan terhadap variabel pengelolaan keuangan, sedangkan variabel transparansi tidak memiliki pengaruh signifikan terhadap pengelolaan keuangan. Akuntabilitas adalah bentuk pertanggungjawaban pihak madrasah dalam mengelola keuangan. Adanya akuntabilitas yang baik dari akan meningkatkan pengelolaan keuangan yang baik pula, sehingga pada akhirnya akan meningkatkan kinerja madrasah.

Transparansi masih merupakan hal yang sulit untuk diterapkan pada ranah pendidikan. Transparansi menuntut adanya penyediaan informasi dan kemudahan akses untuk memperoleh informasi yang akurat dan memadai, dalam hal ini informasi keuangan. Transparansi keuangan di madrasah akan meningkatkan kepercayaan timbal balik antara stakeholders dengan pihak madrasah. Masih adanya anggapan bahwa masalah keuangan adalah hal yang rahasia, makin menjelaskan bahwa transparansi keuangan akan sulit untuk terwujud.

Pihak madrasah adalah sebagai pelaksana dan bekerja berdasarkan kepercayaan dari pihak yang memberikan wewenang dalam hal ini pemerintah dengan menggunakan dana yang diperoleh dari masyarakat. Masyarakat menginginkan adanya transparansi dalam hal pengelolaan keuangan. Transparansi ini juga merupakan salah satu bentuk pengawasan terhadap penggunaan dana oleh pihak madrasah, selain itu juga menunjukkan bahwa madrasah memiliki kepercayaan diri bahwa apa yang telah dilakukan adalah hal yang benar dan tidak ada penyimpangan dari ketentuan yang berlaku.

Akuntabilitas dan transparansi adalah elemen penting dan memiliki pengaruh yang besar dalam pelaksanaan pengelolaan keuangan madrasah. Keduanya saling mendukung dan merupakan satu paket yang tidak terpisahkan. 
Pelaksanaan akuntabilitas dan transparansi yang baik akan meningkatkan kepercayaan dan menambah nilai madrasah di mata stakeholders.

\section{PENUTUP}

\section{Kesimpulan} berikut:

Dari hasil penelitian yang telah dilakukan dapat disimpulkan hal sebagai

1. Secara parsial, akuntabilitas memiliki pengaruh yang signifikan terhadap pengelolaan keuangan madrasah, sedangkan transparansi memiliki pengaruh yang tidak signifikan terhadap pengelolaan keuangan madrasah.

2. Secara simultan, akuntabilitas dan transparansi memiliki pengaruh terhadap pengelolaan keuangan madrasah.

3. Besarnya pengaruh akuntabilitas dan transparansi terhadap pengelolaan keuangan adalah sebesar 53,5\%, sedangkan sisanya sebanyak 46,5\% dipengaruhi oleh faktor lain yang tidak diteliti.

\section{Saran}

Berdasarkan hasil penelitian dan pembahasan pada penelitian ini, maka saran yang dapat diberikan adalah sebagai berikut:

1. Akuntabilitas dalam pengelolaan keuangan madrasah harus ditingkatkan melalui keterlibatan semua pihak dalam penyusunan anggaran. Sehingga tidak ada kepentingan yang terabaikan.

2. Transparansi adalah hal yang mutlak jika ingin melaksanakan pengelolaan keuangan yang baik. Keterbukaan harus lebih ditingkatkan dengan kemampuan untuk menyampaikan APBM melalui media seperti papan pengumuman atau surat.

\section{DAFTAR PUSTAKA}

Eli Solihat dan Toto Sugiharto. 2009. Pengaruh Transparansi dan Akuntabilitas Pengelolaan Pendidikan terhadap Partisipasi Orang Tua Murid di SMA Negeri 107 Jakarta. Jurnal Ekonomi dan Bisnis No. 2 Vol. 14 Agusutus 2009. Download Portal Garuda.

Hendriksen, Eldon S. dan Breda, Michael F. Van. 2013. Teori Akunting. Buku Satu. Interaksara. Batam.

Indra Bastian. 2007. Akuntansi Sektor Publik: Suatu Pengantar. 2006. Penerbit Erlangga: Jakarta.

Indra Bastian. 2007. Akuntansi Pendidikan. Penerbit Erlangga: Jakarta

Mardiasmo. 2002. Akuntansi Sektor Publik. Penerbit Andi: Yogyakarta. 
Monks, Robert A. G. dan Minow, Nell. 2008. Corporate Governance. Fourth Edition. John Wiley \& Sons, Ltd, 2008, West Sussex, England.

Ristya Dwi Anggraini. 2013. Transparansi, Partisipasi dan Akuntabilitas Pengelolaan Anggaran Dana BOS dalam Program RKAS di SDN Pancarkeling VIII Surabaya. Jurnal Kebijakan dan Manajemen Publik Vol. 1 No. 2 Mei - Agustus 2013. Universitas Airlangga. Surabaya.

Syakhroza, Ahmad. 2002. Best Practice Good Corporate Governance dalam Konteks Kondisi Lokal Perbankan Indonesia. Manajemen Usahawan Indonesia No. 06/Tahun XXXII, Juni.

Zamroni. (2008). School Based Management. Yogyakarta: Pascarsarjana Universitas Negeri Yogyakarta. 